\title{
위암에서의 감시림프절수술
}

\author{
신동준 ${ }^{1}$, 손상용 ${ }^{1}$, 김형호 ${ }^{1,2}$ \\ ${ }^{1}$ 서울대학교 의과대학 분당서울대학교병원 외과, ${ }^{2}$ 서울대학교 의과대학 외과학교실
}

\section{Sentinel node navigation surgery in gastric cancer}

\author{
Dong Joon Shin', Sang-Yong Son ${ }^{1}$, Hyung-Ho Kim ${ }^{1,2}$ \\ ${ }^{1}$ Department of Surgery, Seoul National University Bundang Hospital, Seoul National University College of Medicine, Seongnam; ${ }^{2}$ Department of \\ Surgery, Seoul National University College of Medicine, Seoul, Korea
}

The sentinel node (SN) concept has revolutionized surgery for both melanoma and breast cancer over the past two decades. The clinical utility of the SN concept has been confirmed, and individualized treatment based on the status of SNs is well accepted in breast cancer. However, the clinical application of SN navigation surgery (SNNS) for gastric cancer has remained highly controversial during last decade due to the complexity of lymphatic flow in the stomach. A recent meta-analysis and prospective multicenter studies have shown an acceptable rate of detection of SNs and a high accuracy in determining SN status. At present, a dual tracer method using radioactive colloid and vital dye is considered the best means to detect SNs in gastric cancer. Nonetheless, new technologies such as near infrared imaging and fluorescence imaging using indocyanine green have potential to improve the quality of SNNS and change the treatment strategy for gastric cancer. Additionally, rapid intraoperative immunohistochemical staining and intraoperative real-time reverse transcription polymerase chain reaction assay can be used to supplement traditional hematoxylin-eosin staining. In the near future, minimally invasive, function-preserving procedures based on SN mapping of the stomach will likely become increasingly utilized. Herein, the current status of SNNS and individualized treatments for gastric cancer are reviewed.

Keywords: Sentinel lymph node biopsy, Sentinel node, Sentinel node navigation surgery, Gastric cancer

\section{서 론}

감시림프절이란 원발 종양으로부터 관류되는 모든 림프 경로 중 림 프액이 처음으로 도달하는 림프절로서 미세전이 등의 전이가 최초 로 발생할 수 있는 림프절이다[1]. 이론적으로는 감시림프절의 전이 여부로 다른 림프절의 전이 유무를 예측할 수 있어감시림프절에서 전이가 없는 경우 불필요한 림프절 절제를 생략할 수 있다. 현재 감 시림프절수술은 유방암과 흑색종 수술에서 가장 잘 확립되어 있는

Received: Jun 26, 2014 Revised: Jun 26, 2014 Accepted: Jun 27, 2014 Correspondence to: Hyung-Ho Kim

Department of Surgery, Seoul National University Bundang Hospital, Seoul National University College of Medicine, 166 Gumi-ro,

Bundang-gu, Seongnam 463-707, Korea

Tel: +82-31-787-7095, Fax: +82-31-787-4078

E-mail: hhkim@snubh.org

Copyright (C) Korean Society of Surgical Oncology

This is an Open Access article distributed under the terms of the Creative Commons Attribution Non-Commercial License (http://creativecommons.org/licenses/by-nc/3.0) which permits unrestricted non-commercial use, distribution, and reproduction in any medium, provided the original work is properly cited.
데, 유방암 수술의 경우 감시림프절 생검 결과에 따라 겨드랑이 림 프절 절제술을 생략하면서 수술 시간이 크게 단축되었을 뿐만 아니 라 림프 부종, 감각 이상, 상지 거상장애와같은 림프절 절제 관련 합 병증의 발생 빈도가 크게 감소하였다[2,3].

위암 수술에서의 감시림프절수술은 2000년 초 본격적으로 도입 되어 불필요한 림프절 절제를 피하고 위 절제 범위를 최소화하고자 개발되었다[1]. 그러므로, 감시림프절수술은수술 후 조기 합병증을 감소시킬 뿐만 아니라 잔존 위 기능을 최대한 보존하여 덤핑증후군 (dumping syndrome), 경구섭취 제한 및 체중 감소와같은 후기 합병 증을 감소시킴으로써 장기적인 환자의 삶의 질을 향상할 것으로 기 대된다.

지난수 년간 위암의 감시림프절수술에 대하여서는 많은 논쟁이 있었다. 이는 위암의 경우 유방암과 달리 주변 림프 체계가 복잡 다 양하며 도약전이(skip metastasis)에 대한 우려가 많기 때문이다. 하 지만 최근 발표된 메타 분석(meta-analysis) 및 전향적 다기관 임상 연구(prospective multicenter clinical study) 등에서는 90\% 이상의 감 시림프절 검출률(detection rate)과 높은 정확도 (accuracy)를 보고하 고 있고, 기존의 문제점들을 보완하는 새로운 방법들이 개발되고 있 
어 감시림프절수술은 가까운 미래에 비교적 안전하게 시행될 수 있 을 것으로 생각된다[4,5]. 그러나, 현재로써는 감시림프절을 추적하 고 찾는 방법, 병리학적 진단기준 등의 기술적 방법이 정형화되어 있지 않아여전히 임상연구의 단계에 머물러 있다.

최근 진단 기술의 발전으로 암이 조기에 발견되고, 최소 침습 수 술이 보편화 되면서 기능보존수술에 대한 관심이 높아졌다[6-8]. 이 에 저자들은 기능보존수술의 정점이라 할 수 있는 복강경 감시림프 절수술의 현황과 전망을 문헌고찰과 저자들의 경험을 토대로 정리 하고자한다.

\section{본 론}

\section{감시림프절수술의 종양학적 안전성}

위암에서의 감시림프절수술 적응증은 일반적으로 림프절 전이의 가능성은 있으나수술 전 영상 검사에서 림프절 전이가 확인되지 않 은 cT1N0 혹은 cT2N0 환자로 종양의 크기가 $4 \mathrm{~cm}$ 미만인 경우를 대 상으로 한다. 감시림프절 생검의 결과에 따라서 전이 음성으로 판독 되는 경우 내시경점막하절제(endoscopic submucosal dissection), 위 설상절제술(wedge resection), 위분절절제술(segmental resection) 등 의 기능보존수술이 가능하다[1].

위암에서 감시림프절수술의 림프절 절제 범위는 유방암에서처 럼 감시림프절 전이가 없는 경우 추가적 림프절 절제 없이감시림프 절 절제만으로도 충분하다는 이론적 전제에서 시작된다. 하지만, 위의 림프 혈관 체계는 유방암과 달리 매우 복잡한 구조를 가지고 있어 림프액 관류 방향을 쉽게 예측하기 어려울 뿐만 아니라 조기 위암에서도 도약전이, 비감시림프절(non-sentinel node)로의 전이 등이 일부 보고되고 있어 단순히 감시림프절 절제만으로는 불충분 하다는 주장이 있었다[9-11]. 또한 최근 발표된 한 연구에 따르면, 림 프절 전이가 있었던 T1 또는 T2 위암에서 횡단전이(transversal metastasis)가 $10.3 \%$, 도약전이가 $15.8 \%$ 관찰되었고, 이외에도 일부 환자 에서는 비특이적인 림프절 전이(atypical metastasis)가 확인되었다 [12]. 따라서 많은 연구에서 감시림프절이 포함된 림프절 구역의 절 제, 즉 감시림프절 구역(sentinel basin) 절제를 권장하고 있다. 감시 림프절 구역은 위로 주행하는 동맥을 따라, 좌위 동맥(left gastric artery) 구역, 우위 동맥(right gastric artery) 구역, 좌위 대망 동맥(left gastroepiploic artery) 구역, 우위 대망 동맥(right gastroepiploic artery) 구역, 그리고 후위 동맥(posterior gastric artery) 구역 등 다섯 구역으 로 구분된다[13].

감시림프절을 보다 정확하게 검출하기 위한 방법으로는 방사성 콜로이드(radioactive colloid)와 청색 염료(blue dye)를 이용한 이중 추적 방법이 가장 신뢰할 수 있는 방법으로 알려져 있다[14,15]. 이 미 많은 단일 기관 연구를 통해서 이중 추적 방법의 높은 감시림프 절 검출률(90\%-100\%)과 민감도(85\%-100\%) 결과가 보고되었으며, 최근 시행된 다기관 연구에서도 우수한 결과를 보였다 $[4,5,16,17]$. 최근 발표된 메타 분석(38개의 논문, 2,128 명의 환자)에서는, 염료나 동위원소를 이용한 단일 추적 방법의 경우 감시림프절 $92.1 \%$ 의 검 출률, $72.7 \%-76.4 \%$ 의 민감도, $23.6 \%-27.3 \%$ 의 위음성률, $90.1 \%-90.8 \%$
의 정확도를 보인 반면 이중 추적 방법의 경우 감시림프절 $94.0 \%$ 의 검출률, $82.3 \%$ 의 민감도, $17.7 \%$ 의 위음성률, $93.9 \%$ 의 정확도 등의 결 과를 나타내어 단일 추적 방법에 비하여 뛰어나다는 결론을 도출하 였다[4].

저자들 또한 이중 추적 방법을 이용한 복강경 감시림프절수술의 우수성에 대해보고한 바 있다. 2005년 6월부터 2008년 5월까지 cT1$2 \mathrm{~N} 0$ 인 68 명의 환자를 대상으로 인도사이아닌 그린(indocyanine green)과 테크네슘-99m 안티모니 황 콜로이드(Technetium-99m antimony sulfur colloid)를 이용한 감시림프절수술을 진행하였다. 연구 결과 감시림프절 검출률 $92.3 \%$ 로 동위원소를 이용한 단일 추적 방 법과 크게 차이가 없었으나 민감도, 특이도 및 정확도는 모두 $100 \%$ 로 염료나 동위원소만을 이용한 경우보다 향상된 결과를 보였다 [18].

현재까지 감시림프절수술과 관련하여 몇몇 다기관 임상연구가 진행되었다. 대표적인 연구는 일본감시림프절수술학회(Japanese Sentinel Node Navigation Surgery)가 진행한 다기관 전향적 2상 임상 연구로서, 12 개 기관이 참여하여 $4 \mathrm{~cm}$ 미만의 T1-2N0 종양을 대상 으로 표준화된 이중 추적 방법을 이용, 감시림프절 전이 확인에 대 한 민감도 조사를 목표로 진행되었다. 2004년부터 2008년까지 총 443 명에서 감시림프절수술이 이루어졌으며 이중 병리 검사 결과를 통하여 확인된 T1-2병기의 397명에 대하여 분석 결과를 보고하였 다. 연구 결과 감시림프절 검출률은 $97.5 \%$ (387/397), 림프절 전이 정 확도(accuracy of nodal evaluation for metastasis)는 99\% (383/387)였 다. 4 명의 환자 $(7.0 \%, 4 / 57)$ 에서 감시림프절 위음성 판정이 있었는데 이 중 3 명은 $\mathrm{T} 2$ 병기이거나 크기가 $4 \mathrm{~cm}$ 를 초과하는 경우였으며 1 명에서만 감시림프절 구역 외 전이가 확인되었다[5].

한편 비슷한 시기에 진행된 일본임상종양학회(Japanese Clinical Oncology Group)의 다기관 연구는 $4 \mathrm{~cm}$ 미만 T1 병기의 1,550 명을 목표로 진행되었다. 이 연구는 앞서 소개한 일본감시림프절수술학 회의 연구와 달리 감시림프절 검출을 위해 인도사이아닌 그린을 이 용한 단일 추적 방법과 장막하 주입(subserosal injection) 방법을 채 택하였는데, 440 명 모집 후 중간 분석 결과 일차 연구 목표인 위음성 률이 46.4\% (13/28)로 높고 이 중 7명에서 감시림프절 구역 외 전이 가 확인되면서 안정성 문제로 조기 종료되었다[19,20].

최근 국내에서도 감시림프절수술 종양학적 안정성과 관련한 다 기관 연구가 시작되었다[21]. 국내 15 개 기관이 참여한 이 연구는 감 시림프절수술과 관련된 최초의 3 상 임상 연구로서 복강경 위절제 술과 복강경 감시림프절수술의 3 년 무병생존율 비교를 목표로 하 고 있으며 580 명의 피험자 모집 계획이다. 이 연구는 향후 복강경 감 시림프절수술의 향방을 결정하는 유용한 정보를 제공할 것으로 기 대된다.

\section{감시림프절 검출을 위한 진단 도구}

감시림프절 검출을 위한 추적자(tracer)로서 청색 염료(blue dye)와 방사성 동위원소(radioactive isotope)가 가장 많이 이용된다. 청색 염 료는수술 중 림프 관류나감시림프절을 육안적으로 확인할수 있게 해주며, 방사성 동위원소는 육안적으로 확인되지 않는 경우에도 탐 
지기(detector)에 의해 추적할 수 있어 감시림프절 발견 및 감시림프 절 구역 결정에 유용하다. 흔히 청색 염료로서는 이소설판 블루(isosulfan blue), 인도시아닌 그린(indocyanine green) 등이 많이 이용되 며, 방사성 동위원소로는 주로 테그네슘- $99 \mathrm{~m}$ 에 다양한 크기의 콜 로이드를 붙여서 사용하는데, 테크네슘-99m 틴 콜로이드(technetium-99m tin colloid), 테크네슘-99m 황 콜로이드(technetium-99m sulfur colloid), 테크네슘-99m 안티모니 황 콜로이드(technetium-99m antimony sulfur colloid) 등이 많이 이용되고 있다. 저자들은 테크네 슘-99m 안티모니 황 콜로이드 $1.0 \mathrm{mCi}$ 와 인도사이아닌 그린 $4 \mathrm{~mL}$ 를 섞어 추적자로 사용하고 있으며 수술 중 내시경을 통하여 원발 종양주위 네 방향으로 점막하 주입을 하고 있다. 그런 다음 15 분 후 육안적으로 먼저 감시림프절을 감지하고 복강경 탐침자(laparoscopic gamma probe)를 이용하여 감시 림프절 구역을 결정, 림프절 절제를 시행하고 있다. 하지만 현재로서는 염료의 농도 주입, 주입 방법 및 주입 후 탐지자를 이용한 추적시간 등에 대해서 기관별로 다양하게 연구가 진행되고 있어서 이에 대하여 표준화가 이루어지 기까지 많은 연구가 필요할 것으로 보인다.

일부 연구자들은 수술 전 림프신티그라피(lymposcintigraphy)를 이용하여 비특이적 위치에 있는 감시림프절 확인을 시도하였다. 하 지만, 감시림프절 구역확인에 있어 검출률이 낮아 $(67 \%)$ 효용성이 제한적이었으며, 특히 이러한 경향은 체질량 지수가 높은 환자에서 더 뚜렷하였다[22].

컴퓨터단층촬영 림프그라피(computed tomography lymphography)로 감시림프절을 찾기 위한 연구도 진행 되었다. Tsujimoto 등 [23]은 2008년부터 2010년까지 24명의 환자를 대상으로 수술 전 컴 퓨터 단층촬영 림프그라피를 시행하였으며 $83.3 \%$ 의 검출률과 약 $1.3 \pm 0.9$ 개의 감시림프절을 확인할 수 있었다고 보고하였다. $\operatorname{Lim}$ 등 [24]은 14 명의 조기위암 한자에서 시행한 컴퓨터단층촬영 림프그 라피에서 4 명의 환자에서만 감시림프절을 확인하여 $28.6 \%$ 의 낮은 검출률을 보고하였으나, 나노입자 요오드유 에멀젼(nanoscale iodized oil emulsion)을 이용한 예비 연구에서 평균 3.8 개의 감시림프 절과 $100 \%$ 검출률을 보고함으로써 나노입자 요오드유 에멀전을 이 용한 컴퓨터단층촬영 림프그라피가 수술 전 감시림프절 확인에 도 움이 될 수 있음을 시사하였다. 한편 저자들은 24 명의 환자에서 리 피오돌(lipiodol)을 이용하여 컴퓨터단층촬영 림프그라피를 시행하 였으며 평균 2.0 개의 감시림프절과 $95.8 \%$ 의 검출률, 기존 이중 추적 방법과 비교하여 $87 \%$ 일치함을 보고하였다[25].

근래에는 악성 종양의 감시림프절 확인을 위해 단일광자 단층촬 영(single photon emission computed tomography)이 가능하게 되었다 [26]. 단일광자 단층촬영은 방사성 동위원소가 흡수된 조직의 방사 능(radioactivity) 정도를 기존 단층촬영 이미지에 합성하여 보여줌 으로써 방사성 동위원소가 흡수된 부위를 보다 쉽게 확인할 수 있을 뿐만 아니라 주변 구조물과의 관계를 보다 정확히 파악할 수 있다. 현재로는 유방암 등의 다양한 종양에서 감시림프절 감지에 대한 단 일광자 단층촬영의 유용성 연구가 진행되고 있으나 향후 위암의 감 시림프절수술에 적용되어 수술 전 감시림프절 감지 및 구역 확인에 많은 도움이 될 것으로 생각한다[27-29].
최근 인도시아닌 그린의 자연 형광 특성을 이용한 근적외선 형광 이미징(near infrared fluorescence imaging)을 이용한 신기술이 주목 을 받고 있다[30,31]. 기존 생체 염료(vital dye)와 방사성 동위원소를 이용한 이중 추적 방법은 가장 신뢰성이 있지만 방사성 동위원소는 차폐운반, 방사선 노출 측정 등의 복잡한 절차가 필요하여 접근이 용이하지 않다는 단점이 있다. 반면 근적외선 형광 이미징 기술은 별도의 방사성 물질이 필요 없어 안전하고 염료에서는 확인되지 않 는 림프절을 시각적으로 확인할 수 있어 매우 유용한 방법이다. 또 한 염료 입자의 크기가 방사성 콜로이드에 비교하여 현저하게 작아 보다 빠르게 림프절로 퍼져나가 다른 추적 방법보다 넓은 구역에서 림프절을 찾을 수 있다[1]. 그러나 이 기술은 현재로서는 임상적 효 용성 확인 단계에 있다. Tajima 등[32]은 감시림프절 수술 중 인도시 아닌 그린 형광 이미징 기술을 이용하여 $94.7 \%$ 의 감시림프절 검출 률과 $97.2 \%$ 의 정확도, 평균 감시림프절 7 개 이상의 좋은 결과를 보 고하였다. Nimura 등[33]은 적외선 전자 내시경(infrared ray electronic endoscopy)을 이용하여 감시림프절 수술을 시행하였으며 민 감도 $100 \%$, 특이성 $67 \%$, 양성 예측도 $29 \%$ 그리고 음성 예측도 $100 \%$ 의 결과를 보고하였다.

\section{감시림프절수술 중 병리적 진단}

위암수술 중감시림프절 전이 유무를 정확히 진단하는 것은 무엇보 다도 중요하다. 유방암의 경우, 최종 병리검사 결과에 감시림프절 전이가 양성으로 확인되더라도 유방암은 추가적인 림프절 구역 절 제가 용이하고 수술적 치료 외에도 호르몬 치료, 항암치료, 방사선 치료 등의 대안적인 치료가 가능하지만, 위암의 경우 다른 치료의 효과가 매우 제한적이고 위장과 부속 림프절 내에잔존암이 있을 경 우 환자의 예후에 크게 영향을 미칠 수 있기 때문이다. 따라서 위암 의 감시림프절수술을 위해서는 신속하면서 미세전이까지도 확인 할수있는 정확한 병리검사방법이 요구된다.

림프절 전이 유무를 수술 중에 확인하는 기존의 병리검사 방법은 림프절의 최대 절단면을 포함한 몇 장의 슬라이드를 $\mathrm{H \& E}$ 염색(hematotoxyliln and eosin stain, $\mathrm{H} \& \mathrm{E}$ )으로 확인하는 방법으로, 최종 병 리검사 방법인 파라핀 고정절편법(paraffin-embedded section)과 비 교하였을 때 감시림프절의 미세전이 진단이 매우 어렵다. 따라서 근 래에는 미세전이에 대한 병리학적 진단의 민감도 향상을 위해 항사 이토케라틴 항체(anti-cytokeratin antibody)와 같은 면역화학염색 (immunohistochemistry stain)이나 $2 \mathrm{~mm}$ 간격의 동결절편검사(frozen biopsy) 등이 시행되고 있으며 이는 감시림프절 진단에서의 위 음성률을 감소시키는 것으로 보고되었다[34,35].

$2 \mathrm{~mm}$ 간격의 $\mathrm{H \& E}$ 염색 동결절편 감사법이나 면역화학염색법으 로도 진단이 어려운 경우에는 reverse transcription-polymerase chain reaction (RT-PCR) 및 one-step nucleic acid amplification (ONSA)와같 은 분자생물학적인 방법이 도움이 될 수 있다[35,36]. 분자생물학적 인 분석은 기존의 병리학적인 진단 방법과 비교하여 민감도가 높고 전체 림프절을 이용하여 검사할 수 있다는 장점이 있는 반면, 부정 확한 검사 진행 시 위양성 혹은 불충분한 결과를 초래할 수 있기 때 문에 고도의 기술이 요구된다. Osaka 등[37]은 조기위암 환자 57명 
으로부터 절제된 345 개의 림프절(염색 림프절 150 개, 비염색 림프 절 195개)을 대상으로 carcinoembryonic antigen 또는 CK20 mRNA 이용한 실시간 RT-PCT 검사를 시행한 결과, $\mathrm{H \& E}$ 염색상에는 모두 음성이었던 림프절이 RT-PCR 검사에서는 21 개의 림프절에서 양성 으로 확인되었고 이 중 8개만이 사이토케라틴 염색(cytokeratin staining)에서 양성 반응을 보인다고 보고하였다. 특히 미세전이가 있었던 10 명 중 6 명은 단 하나의 림프절에서만 미세전이가 있었음 에도 불구하고 이를 확인할 수 있어 림프절 전이 여부 확인에 RT$\mathrm{PCR}$ 이 유용할 수 있음을 시사하였다. Arigami 등[38]은 림프절 전이 가 없는 T1-2 위암 환자 61명으로부터 감시림프절 절제로 얻은 1,410 개의 림프절에 대하여 조직 병리학적 검사와 실시간 RT-PCR 검사로 비교분석 하였다. 그 결과, $\mathrm{H \& E}$ 염색과 사이토케라틴 염색 에서 각각 5 명 $(8.1 \%), 8$ 명(13.1\%)이 감시림프절 양성 반응을 보인 반 면, RT-PCR 검사를 통해 감시림프절 전이 음성 환자 53 명 중 13 명에 서 추가적으로 림프절 전이가 확인되었다.

\section{복강경 감시림프절수술의 역할 및 전망}

복강경 위절제술은 기존 개복 위절제술에 비해 수술 중 출혈량 감 소, 수술 후 합병증감소, 회복시간의 단축 및 통증 감소 등 많은 장점 을 갖고 있다[39-42]. 그러나 복강경 위절제술은 수술 접근 방법의 최소화를 의미하지 수술 범위의 최소화를 의미하지는 않기 때문에 환자는 복강경 위절제술을 시행받더라도 위절제에 따른 덤핑증후 군, 경구섭취 제한, 빈혈 등의 위절제후증후군(postgastrectomy syndrome)으로부터 자유로울 수 없다[43-45]. 한편 감시림프절수술은 수술 중 림프절 전이 여부를 확인하여 수술 방향을 결정함으로써 환 자 개인별 맞춤형 치료를 가능하게 할 뿐만 아니라 림프절 전이가 없는 환자에서의 불필요한 림프절 절제 및 위절제를 최소화하여 위 절제후증후군과 같은 후기 합병증을 줄이고 장기적으로 환자들의 삶의 질향상을 꾀할수 있다.

복강경 감시림프절수술은 최소침습수술의 장점을 감시림프절 수술에 접목한 수술로서, 수술 후 조기 합병증을 감소시킬 뿐만 아 니라 후기 합병증 또한 감소시킬 수 있는 이상적인 치료 방법으로 장기추적 결과가 매우 기대된다. 현재로서는 복강경 감시림프절수 술에 대하여 연구가 많지 않으나 복강경 감시림프절수술은 기존의 개복 감시림프절수술과 견주어 비슷한 장점을 갖는 것처럼 보인다. Rino 등 [46]은 38명의 환자에서 복강경 감시림프절수술을 시행하 여 $92.1 \%$ 의 검출률, 평균 $2.5 \pm 1.9$ 개의 감시림프절을 보고하였다. 이 는 기존의 개복 감시림프절수술과 비슷한 결과이다. Saikawa 등[47] 은 35 명의 환자에서 이중 추적검사 방법을 이용한 복강경 감시림프 절수술을 시행하였으며 검출률 $94.3 \%$, 정확도는 $97.0 \%$, 평균 감시림 프절 3.9개로 보고하였다. 한편 근래에는 앞서 언급한 형광 이미지 기술을 접목시킨 복강경 감시림프절수술 기법에 대한 연구가 점차 늘고 있다[30,48-52].

복강경 감시림프절 생검 후 전이가 확인된다면 복강경 위절제술 및 광범위 림프절 절제를 시행해야겠지만 전이가 없는 환자라면 개 복수술과마찬가지로 다양한 복강경 기능보존수술을 시행할 수 있 다. 가령, 종양이 위의 대만곡(greater curvature) 부위에 위치하고 감
시림프절 구역 또한 대만곡 구역이라면 복강경 설상절제술이 가능 하며, 감시림프절 구역이 대만곡과 소만곡(lesser curvature)에서 동 시에 발견되고 종양이 유문부(pylorus)로부터 $4 \mathrm{~cm}$ 이상 떨어져 위 치한 경우라면 복강경 유문보존위절제술(laparoscopic pylorus-preserving gastrectomy)을 시행할 수 있다. 또한, 종양이 위 상부에 위치 한 경우 복강경 근위부절제술(laparoscopic proximal gastrectomy)을 시행할수 있다[10,53-55].

한편, 크기가작고 내시경적으로 접근이 가능한 위치의 조기위암 이라면 내시경적 절제술(endoscopic resection)을 시행해볼 수 있다 [56]. 내시경적 절제술은 위를 절제하지 않고 전체를 보존할 수 있어 이론적으로는 가장 이상적인 기능보존 수술이다. 그러나 현재로써 는 매우 제한적인 경우에서만 적용 가능하며 일반적으로 적용되기 에는 좀더 연구가 필요하다. 특히 내시경 절제술 후 발생할 수 있는 국소적인 재발이나 잔존위암 발생 가능성 등의 문제점들은 감시림 프절수술 적용에 앞서 해결되어야할 것이다.

\section{결 론}

복강경 감시림프절수술은 수술 후 합병증을 줄이고 장기적으로 환 자의 삶의 질을 향상시킬 수 있는 환자 개인별 맞춤 수술로 향후 조 기위암치료의 새로운 방향을 제시할 것으로 생각한다.

\section{CONFLICT OF INTEREST}

No potential conflict of interest relevant to this article was reported.

\section{REFERENCES}

1. Takeuchi H, Kitagawa Y. Sentinel node navigation surgery in patients with early gastric cancer. Dig Surg 2013;30:104-11.

2. Giuliano AE, Kirgan DM, Guenther JM, Morton DL. Lymphatic mapping and sentinel lymphadenectomy for breast cancer. Ann Surg 1994;220:391-8.

3. Morton DL, Wen DR, Wong JH, Economou JS, Cagle LA, Storm FK, et al. Technical details of intraoperative lymphatic mapping for early stage melanoma. Arch Surg 1992;127:392-9.

4. Wang Z, Dong ZY, Chen JQ, Liu JL. Diagnostic value of sentinel lymph node biopsy in gastric cancer: a meta-analysis. Ann Surg Oncol 2012;19:1541-50.

5. Kitagawa Y, Takeuchi H, Takagi Y, Natsugoe S, Terashima M, Murakami N, et al. Sentinel node mapping for gastric cancer: a prospective multicenter trial in Japan. J Clin Oncol 2013;31:3704-10.

6. Can MF, Yagci G, Cetiner S. Systematic review of studies investigating sentinel node navigation surgery and lymphatic mapping for gastric cancer. J Laparoendosc Adv Surg Tech A 2013;23:651-62.

7. Shinohara T, Kanaya S, Taniguchi K, Fujita T, Yanaga K, Uyama I. Laparoscopic total gastrectomy with D2 lymph node dissection for 
gastric cancer. Arch Surg 2009;144:1138-42.

8. Hur H, Jeon HM, Kim W. Laparoscopy-assisted distal gastrectomy with D2 lymphadenectomy for T2b advanced gastric cancers: three years' experience. J Surg Oncol 2008;98:515-9.

9. Ishikawa K, Yasuda K, Shiromizu A, Etoh T, Shiraishi N, Kitano S. Laparoscopic sentinel node navigation achieved by infrared ray electronic endoscopy system in patients with gastric cancer. Surg Endosc 2007;21:1131-4.

10. Takeuchi H, Oyama T, Kamiya S, Nakamura R, Takahashi T, Wada $\mathrm{N}$, et al. Laparoscopy-assisted proximal gastrectomy with sentinel node mapping for early gastric cancer. World J Surg 2011;35:246371.

11. Kitagawa Y, Saikawa Y, Takeuchi H, Mukai M, Nakahara T, Kubo A, et al. Sentinel node navigation in early stage gastric cancer: updated data and current status. Scand J Surg 2006;95:256-9.

12. Lee JH, Lee HJ, Kong SH, Park do J, Lee HS, Kim WH, et al. Analysis of the lymphatic stream to predict sentinel nodes in gastric cancer patients. Ann Surg Oncol 2014;21:1090-8.

13. Kinami S, Fujimura T, Ojima E, Fushida S, Ojima T, Funaki H, et al. PTD classification: proposal for a new classification of gastric cancer location based on physiological lymphatic flow. Int J Clin Oncol 2008;13:320-9.

14. Kitagawa Y, Fujii H, Kumai K, Kubota T, Otani Y, Saikawa Y, et al. Recent advances in sentinel node navigation for gastric cancer: a paradigm shift of surgical management. J Surg Oncol 2005;90:14751.

15. Kitagawa Y, Kitajima M. Diagnostic validity of radio-guided sentinel node mapping for gastric cancer: a review of current status and future direction. Surg Technol Int 2006;15:32-6.

16. Kitagawa Y, Fujii H, Mukai M, Kubota T, Ando N, Watanabe M, et al. The role of the sentinel lymph node in gastrointestinal cancer. Surg Clin North Am 2000;80:1799-809.

17. Kitagawa Y, Fujii H, Mukai M, Kubo A, Kitajima M. Sentinel lymph node mapping in esophageal and gastric cancer. Cancer Treat Res 2005;127:123-39.

18. Park do J, Kim HH, Park YS, Lee HS, Lee WW, Lee HJ, et al. Simultaneous indocyanine green and $(99 \mathrm{~m}) \mathrm{Tc}$-antimony sulfur colloid-guided laparoscopic sentinel basin dissection for gastric cancer. Ann Surg Oncol 2011;18:160-5.

19. Miyashiro I. What is the problem in clinical application of sentinel node concept to gastric cancer surgery? J Gastric Cancer 2012;12:712.

20. Miyashiro I, Hiratsuka M, Sasako M, Sano T, Mizusawa J, Nakamura K, et al. High false-negative proportion of intraoperative histological examination as a serious problem for clinical application of sentinel node biopsy for early gastric cancer: final results of the Japan Clinical Oncology Group multicenter trial JCOG0302. Gastric
Cancer 2014;17:316-23.

21. ClinicalTrials.gov. Multicenter phase III trial of laparoscopic sentinel node biopsy [Internet]. Bethesda, MD: U.S. National Institutes of Health; 2014 [cited 2014 Jul 9]. Available from: http://www.clinicaltrial.gov/ct2/show/NCT01804998?term=senorita\&rank=1.

22. Nakahara T, Kitagawa Y, Yakeuchi H, Fujii H, Suzuki T, Mukai M, et al. Preoperative lymphoscintigraphy for detection of sentinel lymph node in patients with gastric cancer: initial experience. Ann Surg Oncol 2008; 15:1447-53.

23. Tsujimoto H, Yaguchi Y, Sakamoto N, Kumano I, Takahata R, Matsumoto $\mathrm{Y}$, et al. Computed tomography lymphography for the detection of sentinel nodes in patients with gastric carcinoma. Cancer Sci 2010;101:2586-90.

24. Lim JS, Choi J, Song J, Chung YE, Lim SJ, Lee SK, et al. Nanoscale iodized oil emulsion: a useful tracer for pretreatment sentinel node detection using CT lymphography in a normal canine gastric model. Surg Endosc 2012;26:2267-74.

25. Lee JH, Park do J, Kim YH, Shin CM, Lee HS, Kim HH. Clinical implementations of preoperative computed tomography lymphography in gastric cancer: a comparison with dual tracer methods in sentinel node navigation surgery. Ann Surg Oncol 2013;20:2296303.

26. Vermeeren L, van der Ploeg IM, Olmos RA, Meinhardt W, Klop WM, Kroon BB, et al. SPECT/CT for preoperative sentinel node localization. J Surg Oncol 2010;101:184-90.

27. Zender C, Guo T, Weng C, Faulhaber P, Rezaee R. Utility of SPECT/ CT for periparotid sentinel lymph node mapping in the surgical management of head and neck melanoma. Am J Otolaryngol 2014;35:12-8

28. Vercellino L, Ohnona J, Groheux D, Slama A, Colletti PM, Chondrogiannis S, et al. Role of SPECT/CT in sentinel lymph node detection in patients with breast cancer. Clin Nucl Med 2014;39:431-6.

29. Mihaljevic AL, Rieger A, Belloni B, Hein R, Okur A, Scheidhauer K, et al. Transferring innovative freehand SPECT to the operating room: first experiences with sentinel lymph node biopsy in malignant melanoma. Eur J Surg Oncol 2014;40:42-8.

30. Tajima Y, Murakami M, Yamazaki K, Masuda Y, Kato M, Sato A, et al. Sentinel node mapping guided by indocyanine green fluorescence imaging during laparoscopic surgery in gastric cancer. Ann Surg Oncol 2010;17:1787-93.

31. Miyashiro I, Miyoshi N, Hiratsuka M, Kishi K, Yamada T, Ohue M, et al. Detection of sentinel node in gastric cancer surgery by indocyanine green fluorescence imaging: comparison with infrared imaging. Ann Surg Oncol 2008;15:1640-3.

32. Tajima Y, Yamazaki K, Masuda Y, Kato M, Yasuda D, Aoki T, et al. Sentinel node mapping guided by indocyanine green fluorescence imaging in gastric cancer. Ann Surg 2009;249:58-62. 
33. Nimura H, Narimiya N, Mitsumori N, Yamazaki Y, Yanaga K, Urashima M. Infrared ray electronic endoscopy combined with indocyanine green injection for detection of sentinel nodes of patients with gastric cancer. Br J Surg 2004;91:575-9.

34. Lee HS, Lee HE, Park DJ, Park YS, Kim HH. Precise pathologic examination decreases the false-negative rate of sentinel lymph node biopsy in gastric cancer. Ann Surg Oncol 2012;19:772-8.

35. Takeuchi H, Kitajima M, Kitagawa Y. Sentinel lymph node as a target of molecular diagnosis of lymphatic micrometastasis and local immunoresponse to malignant cells. Cancer Sci 2008;99:441-50.

36. Matsuda J, Kitagawa Y, Fujii H, Mukai M, Dan K, Kubota T, et al. Significance of metastasis detected by molecular techniques in sentinel nodes of patients with gastrointestinal cancer. Ann Surg Oncol 2004;11(3 Suppl):250S-4S.

37. Osaka H, Yashiro M, Sawada T, Katsuragi K, Hirakawa K. Is a lymph node detected by the dye-guided method a true sentinel node in gastric cancer? Clin Cancer Res 2004;10:6912-8.

38. Arigami T, Natsugoe S, Uenosono Y, Mataki Y, Ehi K, Higashi H, et al. Evaluation of sentinel node concept in gastric cancer based on lymph node micrometastasis determined by reverse transcription-polymerase chain reaction. Ann Surg 2006;243:341-7.

39. Kim YW, Baik YH, Yun YH, Nam BH, Kim DH, Choi IJ, et al. Improved quality of life outcomes after laparoscopy-assisted distal gastrectomy for early gastric cancer: results of a prospective randomized clinical trial. Ann Surg 2008;248:721-7.

40. Lee SI, Choi YS, Park DJ, Kim HH, Yang HK, Kim MC. Comparative study of laparoscopy-assisted distal gastrectomy and open distal gastrectomy. J Am Coll Surg 2006;202:874-80.

41. Hwang SH, Park do J, Kim YH, Lee KH, Lee HS, Kim HH, et al. Laparoscopic surgery for submucosal tumors located at the esophagogastric junction and the prepylorus. Surg Endosc 2009;23:1980-7.

42. Kim HH, Hyung WJ, Cho GS, Kim MC, Han SU, Kim W, et al. Morbidity and mortality of laparoscopic gastrectomy versus open gastrectomy for gastric cancer: an interim report: a phase III multicenter, prospective, randomized Trial (KLASS Trial). Ann Surg 2010;251:417-20.

43. Carvajal SH, Mulvihill SJ. Postgastrectomy syndromes: dumping and diarrhea. Gastroenterol Clin North Am 1994;23:261-79.

44. Lee JH, Hyung WJ, Kim HI, Kim YM, Son T, Okumura N, et al. Method of reconstruction governs iron metabolism after gastrectomy for patients with gastric cancer. Ann Surg 2013;258:964-9.

45. Kiyama T, Mizutani T, Okuda T, Fujita I, Tokunaga A, Tajiri T, et al. Postoperative changes in body composition after gastrectomy. J Gastrointest Surg 2005;9:313-9.
46. Rino Y, Takanashi Y, Harada H, Ashida A, Saeki H, Yukawa N, et al. Technique and assessment of sentinel lymph node biopsy usefulness in laparoscopy-assisted distal gastrectomy. Surg Endosc 2006;20: 1887-91.

47. Saikawa Y, Otani Y, Kitagawa Y, Yoshida M, Wada N, Kubota T, et al. Interim results of sentinel node biopsy during laparoscopic gastrectomy: possible role in function-preserving surgery for early cancer. World J Surg 2006;30:1962-8.

48. Kong SH, Noh YW, Suh YS, Park HS, Lee HJ, Kang KW, et al. Evaluation of the novel near-infrared fluorescence tracers pullulan polymer nanogel and indocyanine green/gamma-glutamic acid complex for sentinel lymph node navigation surgery in large animal models. Gastric Cancer 2014 Jan 31 [Epub]. http://dx.doi.org/10.1007/s10120014-0345-3.

49. Kubota K, Yoshida M, Kuroda J, Okada A, Ohta K, Kitajima M. Application of the HyperEye Medical System for esophageal cancer surgery: a preliminary report. Surg Today 2013;43:215-20.

50. Yoshida M, Kubota K, Kuroda J, Ohta K, Nakamura T, Saito J, et al. Indocyanine green injection for detecting sentinel nodes using color fluorescence camera in the laparoscopy-assisted gastrectomy. J Gastroenterol Hepatol 2012;27 Suppl 3:29-33.

51. Fujita T, Seshimo A, Kameoka S. Detection of sentinel nodes in gastric cancer by indocyanine green fluorescence imaging. Hepatogastroenterology 2012;59:2213-6.

52. Miyashiro I, Kishi K, Yano M, Tanaka K, Motoori M, Ohue M, et al. Laparoscopic detection of sentinel node in gastric cancer surgery by indocyanine green fluorescence imaging. Surg Endosc 2011;25: 1672-6.

53. Ahn SH, Lee JH, Park do J, Kim HH. Comparative study of clinical outcomes between laparoscopy-assisted proximal gastrectomy (LAPG) and laparoscopy-assisted total gastrectomy (LATG) for proximal gastric cancer. Gastric Cancer 2013;16:282-9.

54. Lee SW, Bouras G, Nomura E, Yoshinaka R, Tokuhara T, Nitta T, et al. Intracorporeal stapled anastomosis following laparoscopic segmental gastrectomy for gastric cancer: technical report and surgical outcomes. Surg Endosc 2010;24:1774-80.

55. Lee JH, Lee MS, Kim HH, Park do J, Lee KH, Hwang JY, et al. Feasibility of laparoscopic partial gastrectomy with sentinel node basin dissection in a porcine model. Surg Endosc 2011;25:1070-5.

56. Gotoda T, Yanagisawa A, Sasako M, Ono H, Nakanishi Y, Shimoda T, et al. Incidence of lymph node metastasis from early gastric cancer: estimation with a large number of cases at two large centers. Gastric Cancer 2000;3:219-25. 